\title{
Genomic divergences among cattle, dog and human estimated from large-scale alignments of genomic sequences
}

\author{
George E Liu*1, Lakshmi K Matukumalli1,2, Tad S Sonstegard ${ }^{1}$, Larry L Shade ${ }^{1}$ \\ and Curtis P Van Tassell ${ }^{1}$
}

\begin{abstract}
Address: ${ }^{1}$ USDA, ARS, ANRI, Bovine Functional Genomics Laboratory, Beltsville Agricultural Research Center (BARC) - East, 10300 Baltimore Avenue, Beltsville, MD, 20705, USA and 2Bioinformatics and Computational Biology, George Mason University, Manassas, VA 20110, USA

Email: George E Liu* - gliu@anri.barc.usda.gov; Lakshmi K Matukumalli - lmatukum@gmu.edu; Tad S Sonstegard - tads@anri.barc.usda.gov; Larry L Shade - lshade@anri.barc.usda.gov; Curtis P Van Tassell - curtvt@anri.barc.usda.gov

* Corresponding author
\end{abstract}

Published: 07 June 2006

BMC Genomics 2006, 7:140 doi:10.1186/147|-2164-7-140

This article is available from: http://www.biomedcentral.com//47/-2/64/7//40

(c) 2006 Liu et al; licensee BioMed Central Ltd.

This is an Open Access article distributed under the terms of the Creative Commons Attribution License (http://creativecommons.org/licenses/by/2.0), which permits unrestricted use, distribution, and reproduction in any medium, provided the original work is properly cited.
Received: 09 January 2006

Accepted: 07 June 2006

\begin{abstract}
Background: Approximately II Mb of finished high quality genomic sequences were sampled from cattle, dog and human to estimate genomic divergences and their regional variation among these lineages.

Results: Optimal three-way multi-species global sequence alignments for 84 cattle clones or loci (each $>50 \mathrm{~kb}$ of genomic sequence) were constructed using the human and dog genome assemblies as references. Genomic divergences and substitution rates were examined for each clone and for various sequence classes under different functional constraints. Analysis of these alignments revealed that the overall genomic divergences are relatively constant $(0.32-0.37$ change/site) for pairwise comparisons among cattle, dog and human; however substitution rates vary across genomic regions and among different sequence classes. A neutral mutation rate $(2.0-2.2 \times 10(-9)$ change/site/year) was derived from ancestral repetitive sequences, whereas the substitution rate in coding sequences $(\mathrm{I} . \mathrm{I} \times \mathrm{IO}(-9)$ change/site/year) was approximately half of the overall rate (I.9$2.0 \times 10(-9)$ change/site/year). Relative rate tests also indicated that cattle have a significantly faster rate of substitution as compared to dog and that this difference is about $6 \%$.
\end{abstract}

Conclusion: This analysis provides a large-scale and unbiased assessment of genomic divergences and regional variation of substitution rates among cattle, dog and human. It is expected that these data will serve as a baseline for future mammalian molecular evolution studies.

\section{Background}

Many mammalian species have long served our human society by providing food, materials, and labor, providing companionship as pets, and serving as model organisms for biological studies. Besides the seven mammals (human, mouse, rat, chimpanzee, macaque, dog and cattle) whose genomic sequence data are already available,
16 eutherian mammals have been proposed for low-coverage genome sequencing efforts [1]. Comparative genomics has been proven to be a powerful strategy to identify important evolutionary changes among these mammalian species [2]. Evolutionary changes, which have shaped the mammalian genomes, include both small-scale (point mutations, microsatellite slippage, 
insertions/deletions) as well as large-scale events (transpositions, genomic rearrangements and segmental duplications). Knowledge of mutation rates is critical for building evolutionary timescale, discovering conserved noncoding functional elements, identifying evolutionary processes like positive selection, and understanding heritable diseases [3].

Earlier studies on mammalian evolution were limited by the lack of large-scale genomic sequence data and were dependent upon PCR cross-amplification of limited numbers of mitochondrial and nuclear genes. Therefore, these sampled sequences were often limited to closely related species and had a bias towards conserved unique regions. This also resulted in repetitive sequences being excluded from genomic divergence calculations in these earlier studies. As the remnants of transposition events, repetitive sequences are one of the most predominant features of mammalian genomes (for example, $40-50 \%$ of the human genome are repeats) [4,5]. Repeats have been shown to play an important role in mammalian genome evolution $[6,7]$. Depending on their time of origin, repeats can be divided into ancestral repeats (AR: arrived before a speciation event, and thus shared by both species) and lineage-specific repeats (arrived after a speciation event). Recently it has been shown that virtually all ancient repeats evolve neutrally [8]. As one class of nonfunctional neutral sequences, ancient repeats have been used to estimate neutral mutation rates [9-11]. Several recent studies have indicated that neutral mutation rates (not substitution rates which are the combined effects of mutation and selection) in mammals have been relatively constant [12], except for the discrepant results from rodents, which were shown to mutate as much as 2-fold faster than other mammals $[9,11]$.

With the availability of the human, mouse, rat and chimpanzee genome assemblies, whole genome-wide comparisons and analyses have been generated using primates and rodents (such as human vs. non-human primates, mouse, and rat) $[4,5,9,13-15]$. Targeted comparative sequencing efforts (the ENCODE - ENCyclopedia Of DNA Elements Project) also have generated megabases of high-quality genomic sequence for dozens of mammalian species $[2,16,17]$. Recent studies also have measured mutation rates [18], their regional variation $[19,20]$ and their covariation with other genomic events in human, mouse and rat $[11,21]$. A local alignment algorithm, blastz [22], has been used to align human, mouse and rat genomes $[9,14,21]$. On the other hand, a global alignment algorithm, mlagan, has been used to generate multiple alignments in the "greater CFTR region" [23]. A comparison of results derived from local versus global alignment algorithms would be of interest.
With the dog draft assembly (July 2004, canFam1)[24], the cattle draft assembly (March 2005, bosTau2)[25] and cattle BAC library resources [26] now available, a largescale genomic comparison was initiated to assess the nature and pattern of genomic variation among other mammalian orders; i.e. artiodactyls (Cattle, Bos taurus) and carnivores (Dog, Canis familiaris) as compared to primates (Human, Homo sapiens). To avoid any potential genome assembly artifacts, the project began with highquality finished genomic sequences from cattle BAC clones, rather than the cattle draft assembly. The threeway multi-species global alignments (ranging in alignment length from 67 to $491 \mathrm{~kb}$ ) were generated from the orthologous sequences of cattle, dog and human using an optimized global alignment algorithm to provide a platform for analyzing genomic variation. The lineage, which led to the last common ancestor (LCA) of cattle and dog, was estimated to have diverged from human approximately 92 million years ago (mya) followed by the estimated separation of cattle and dog 83 million years ago $[27,28]$. The overall objective of this study was to assess patterns of single-nucleotide mutations across genomic regions and among different sequence classes in the mammalian lineages.

\section{Results \\ Orthologous sequences and alignment validation}

A total of 84 ortholog trios were identified though a sequence similarity search, which included $10.5 \mathrm{Mb}$ of cattle sequences, $9.3 \mathrm{Mb}$ of dog sequences and $11.1 \mathrm{Mb}$ of human sequences. The putative ortholog trios were further confirmed by reciprocal blast [29]. These ortholog trios were placed to all human chromosomes (chr) except for chr 9, 15, 19 and Y (see Additional file 1 Table S3).

Two strategies were implemented to align these orthologous sequences using the global alignment algorithm mlagan: 1) optimizing the alignment parameters and 2) applying a post-alignment filter. In order to establish the optimal parameters to treat indels in global alignment, 5 random sets of pairwise sequence alignments were analyzed between cattle-dog, cattle-human and dog-human. Using the software lagan [23], a series of gap opening and extension penalties were tested for their impact on the frequency of single nucleotide and insertion/deletion events (see Additional file $1 \mathrm{Fig}$. S1). The following tests were performed to select the optimal alignment parameters that minimized sequence divergence and the number of indels. First, the natures of the sequences underlying insertion/deletions were analyzed. Alignment parameters (gap opening penalty of $-1,000$ and gap extension penalty of -10) were favored because insertion/deletions were effectively treated as a single event. Second, the overall estimates of sequence divergence (Table 1) were compared with earlier phylogenetic studies using conserved 


\begin{tabular}{|c|c|c|c|c|c|c|c|c|c|c|}
\hline & \multirow[t]{2}{*}{ \# loci } & \multirow{2}{*}{$\begin{array}{l}\text { Total length } \\
\text { (bp) }\end{array}$} & \multirow{2}{*}{$\begin{array}{l}\text { Aligned length } \\
\text { (bp) }\end{array}$} & \multirow[t]{2}{*}{ Tree length } & \multicolumn{3}{|c|}{ Branch length } & \multicolumn{3}{|c|}{ Substitution rate* $\left(\right.$ change/site $\left.\times 10^{-9}\right)$} \\
\hline & & & & & Cattle & Dog & Human & Cattle & Dog & Human \\
\hline Overall $\dagger$ & 84 & 15507060 & 5521247 & 0.5265 & $0.1681 \pm 0.0003$ & $0.1547 \pm 0.0003$ & $0.2036 \pm 0.0003$ & $2.026 \pm 0.003$ & $1.864 \pm 0.003$ & $2.016 \pm 0.003$ \\
\hline Overall-CG & 84 & 15507060 & 5282306 & 0.4984 & $0.1595 \pm 0.0003$ & $0.1451 \pm 0.0002$ & $0.1938 \pm 0.0003$ & $1.921 \pm 0.003$ & $1.748 \pm 0.003$ & $1.919 \pm 0.003$ \\
\hline Coding & 52 & 137748 & 133235 & 0.1886 & $0.0644 \pm 0.0010$ & $0.0647 \pm 0.0010$ & $0.0595 \pm 0.0009$ & $0.776 \pm 0.012$ & $0.780 \pm 0.012$ & $0.589 \pm 0.009$ \\
\hline UTR & 55 & 152130 & 115467 & 0.3855 & $0.1223 \pm 0.0016$ & $0.1472 \pm 0.0018$ & $0.1161 \pm 0.0015$ & $1.473 \pm 0.019$ & $1.773 \pm 0.022$ & $1.059 \pm 0.010$ \\
\hline $\begin{array}{l}\text { Unique } \\
\text { noncoding }\end{array}$ & 84 & 9073616 & 4061797 & 0.5235 & $0.1676 \pm 0.0003$ & $0.1538 \pm 0.0003$ & $0.2021 \pm 0.0004$ & $2.019 \pm 0.004$ & $1.853 \pm 0.003$ & $2.001 \pm 0.004$ \\
\hline Repetitive & 84 & 6409365 & II57484 & 0.5719 & $0.1830 \pm 0.0006$ & $0.1668 \pm 0.0006$ & $0.2221 \pm 0.0007$ & $2.205 \pm 0.007$ & $2.010 \pm 0.007$ & $2.199 \pm 0.007$ \\
\hline Repetitive-CG & 84 & 6409365 & 1112423 & 0.5460 & $0.1749 \pm 0.0006$ & $0.1581 \pm 0.0006$ & $0.2129 \pm 0.0007$ & $2.108 \pm 0.007$ & $1.905 \pm 0.007$ & $2.108 \pm 0.007$ \\
\hline
\end{tabular}

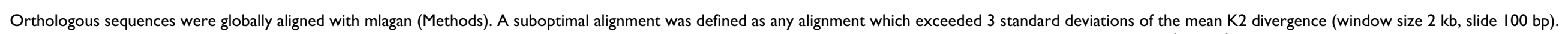

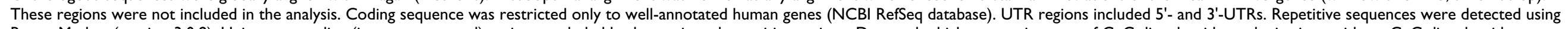

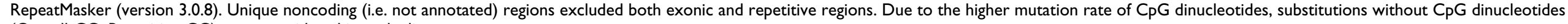
(Overall-CG, Repetitive-CG) were considered in each alignment.

* Substitution rate calculations assume branch times of the cattle, dog and human lineages from the LCA of cattle and dog of 83,83 and I0I mya, respectively [27,28].

$t$ : If suboptimal alignments were included in the analysis, the overall branch length increases to $0.1707 \pm 0.0003,0.1567 \pm 0.0003$ and $0.2069 \pm 0.0004$, respectively (Methods).

coding regions $[12,30]$ or the greater CFTR region aligned by blastz [2]. The estimated overall sequence divergences in our analyses (cattle-dog: $0.3228 \pm 0.0005$, cattle-human: $0.3717 \pm 0.0007$, and dog-human: $0.3583 \pm 0.0006$ change/site) were generally comparable to previous studies $[2,10,12,30]$. Third, 73,728 randomly selected cattle BAC end sequences (BES) from CHORI-240 [31] were mapped onto the human genome assembly Build35 [32]. Similar results were observed when alignments of BAC end sequences were compared with our optimal global alignments. The variation distribution pattern of these BES alignments (400-500 bp) (G.E. Liu et al, unpublished results) was remarkably similar to the distribution observed for non-overlapping 500-bp windows generated from optimal global alignments (see Additional file 1 Fig. S5B).

Despite the optimization of alignment parameters, suboptimal or ectopic alignments occasionally occurred. Suboptimal alignments were defined as those alignments that exceeded 3 standard deviations of the mean pairwise K2 divergences in a sliding window analysis (See Methods), which were removed using a post-alignment filter. Although such suboptimal alignments composed less than $5 \%$ of aligned bases, these alignments were not considered in our analysis to avoid overestimation of genomic divergence.

A total of 84 three-way multiple sequence alignments were generated with a combined alignment length of $15 \mathrm{Mb}$, consisting of $5.5 \mathrm{Mb}$ of aligned bases and 1,794 non-overlapping windows of $3 \mathrm{~kb}$ (Fig. 1 and Additional file 1 Fig. S5A). The cattle-dog-human multiple alignment lengths ranged from 66,960 to 491,059 bp with a mean and standard deviation of $184,608 \pm 79,744 \mathrm{bp}$. All individual alignments and patterns of single-nucleotide variation were manually inspected and are available online [33].

\section{Branch lengths in various sequence classes}

Comparative genomic analyses were performed on these 84 three-way multi-species global alignments. The branch lengths and substitution rates of cattle, dog and human are shown in Table 1 . The average overall branch lengths were $0.1681 \pm 0.0003,0.1547 \pm$ 0.0003 , and $0.2036 \pm 0.0003$ change/site for cattle, dog and human, respectively. Similar degrees of branch lengths were reported in previous studies $[12,30]$. The genomic divergence between cattle and dog was the smallest with a value of $0.3228 \pm 0.0005$ change/ site. The dog-human evolutionary divergence was $0.3583 \pm 0.0006$ change/site, which was less than the cattle-human divergence of $0.3717 \pm 0.0006$ change/site. As expected, these results confirm that artiodactyls and carnivores are the closest relatives, with primates being the most distant. Mutations at CpG dinucleotides occur frequently due to spontaneous deamination of methylated cytosines [34]. To remove any variation caused by differences in levels of methylation, substitution rates were estimated after removing CpG dinucleotides (Overall-CG, Repetitive-CG). The overall branch lengths decreased 5.1\% (cattle), 6.2\% (dog) and 4.8\% (human) after removing CpG dinucleotides from all sequences within alignments (Table 1, Overall-CG). Alignments were further sorted into four sequence classes based on NCBI RefSeq [35] and RepeatMasker coordinates using the software MaM [36]. The total $5.5 \mathrm{Mb}$ aligned sequences included $133 \mathrm{~kb}, 115 \mathrm{~kb}, 4.0 \mathrm{Mb}$ and $1.2 \mathrm{Mb}$ aligned bases from coding, UTR, unique noncoding (i.e. not annotated), and repetitive regions, respectively. Coding regions of 193 well-annotated RefSeq genes excluded both 3' and 5' UTR. Branch lengths in coding regions (cattle 0.0644 \pm 0.0010 , $\operatorname{dog} 0.0647 \pm 0.0010$, and human $0.0595 \pm 0.0009$ change/site) were only half of the overall branch length, reflecting that they are under strong purifying selection. The branch lengths in UTR regions (cattle $0.1676 \pm 0.0003$, dog $0.1538 \pm 0.0003$, and human 0.2021 \pm 0.0004 change/site) were significantly larger than the coding branch lengths (t-test, for each species $\mathrm{p}<0.0001$ ). The branch lengths in unique noncoding portions (cattle 0.1676 $\pm 0.0003, \operatorname{dog} 0.1538 \pm 0.0003$, and human $0.2021 \pm 0.0004$ change/site) were slightly less than the overall branch lengths. In contrast, the aligned repetitive portions possessed the longest branch lengths (cattle $0.1830 \pm 0.0006$, dog $0.1668 \pm 0.0006$, and human $0.2221 \pm 0.0007$ change/site). These branch lengths decreased $4.4 \%$ (cattle), $5.2 \%$ (dog) and $4.1 \%$ (human) when CpG dinucleotide sites were excluded, suggesting higher substi- 
A

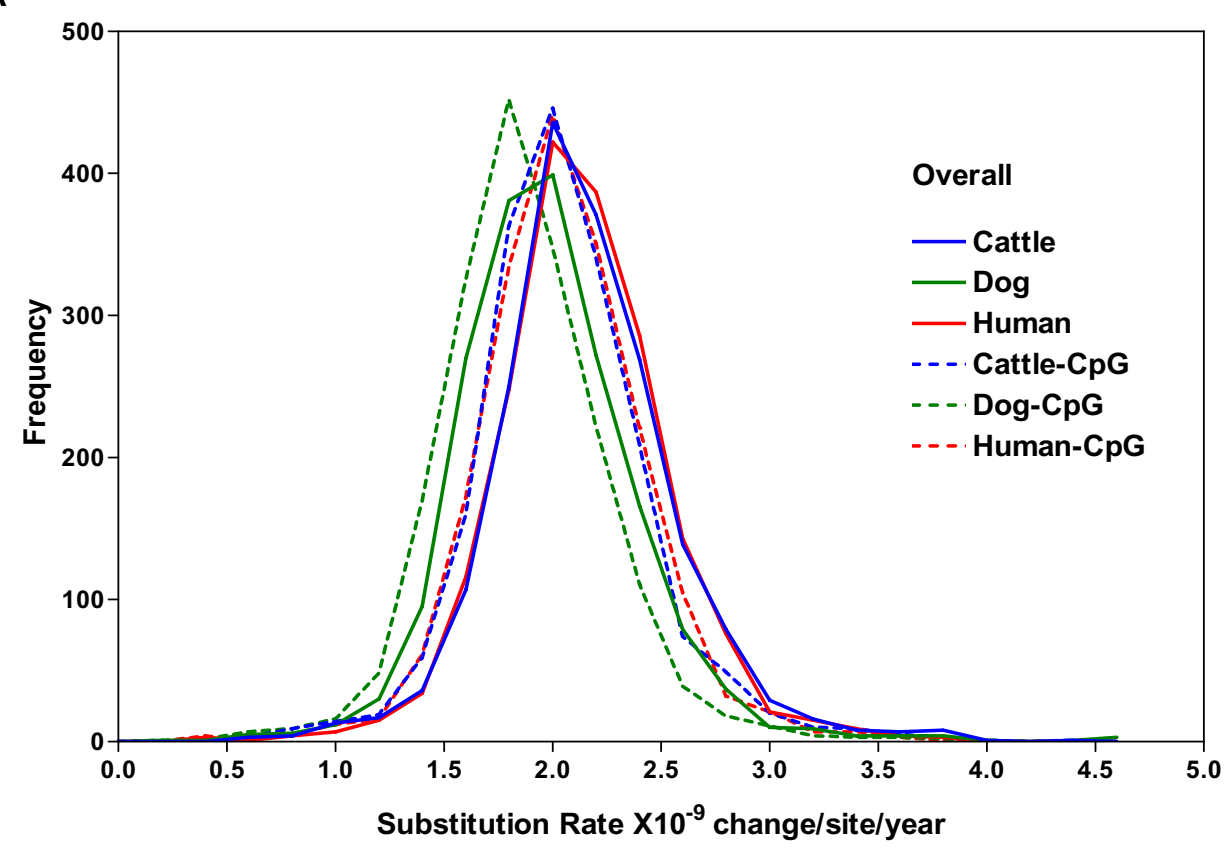

B

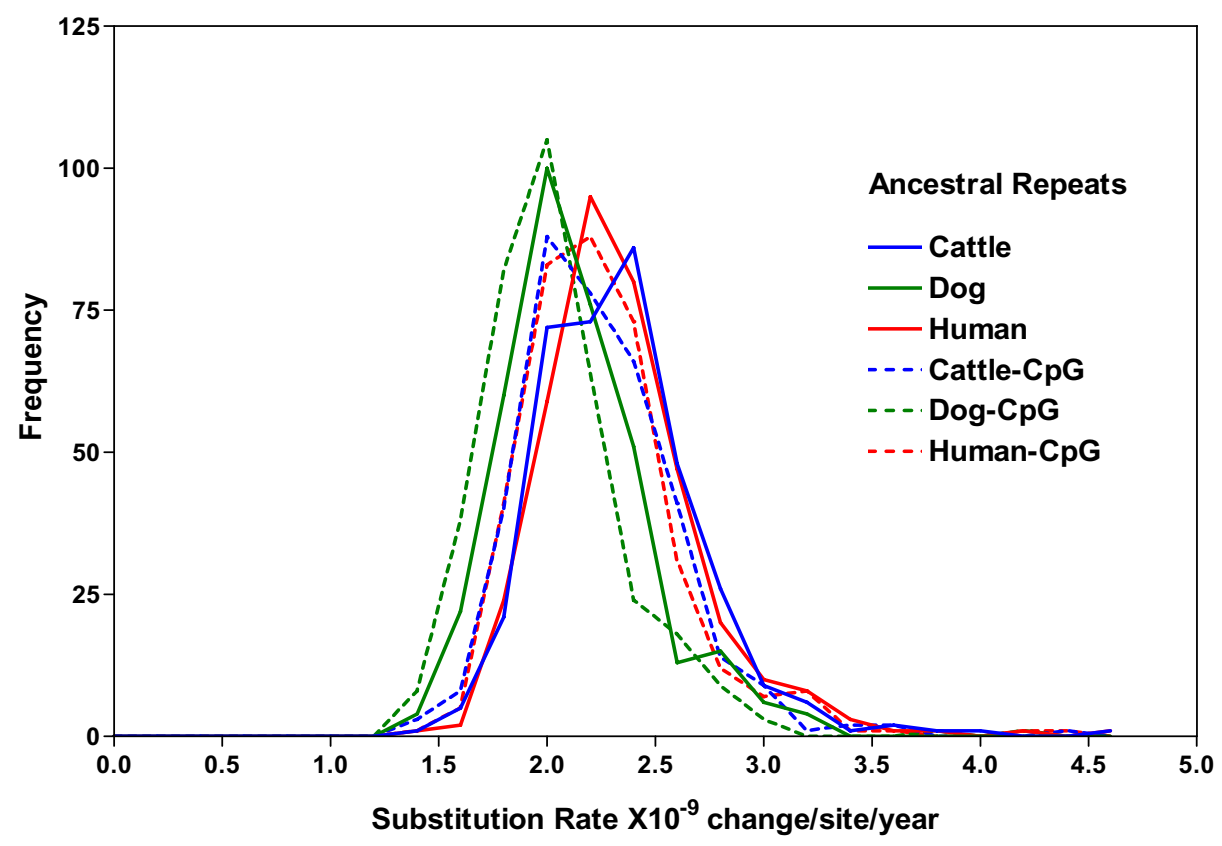

Figure I

Distributions of Substitution Rates in Cattle, Dog and Human. (A) Histograms of the local substitution rates in aligned sequences (84 loci, $5.5 \mathrm{Mb}$ aligned bases, I,794 windows). (B) Histograms of the local substitution rates in aligned ancestral repeats (84 loci, I.2 Mb aligned bases, 353 windows). All measures were computed in non-overlapping 3-kb sliding windows for cattle-dog-human multiple sequence alignments. These rates were calculated in multiple comparisons assuming branch times of the cattle, dog and human lineages from the LCA of cattle and dog of 83, 83 and 10I mya, respectively. Suboptimal alignments were excluded. The cattle branch: blue; the dog branch: green; and the human branch: red. The dashed lines were computed after removing CpG dinucleotides. 
tution rates of CpG sites (Table 1, Repetitive-CG). The differences were significant between the branch lengths in unique noncoding vs. repetitive portions before and after removing $\mathrm{CpG}$ dinucleotides from repetitive elements (one-way ANOVA, cattle $\mathrm{P}=0.0006, \operatorname{dog} \mathrm{P}=0.0116$, and human $\mathrm{P}<0.0001$ ) for all 83 autosomal alignments.

\section{Regional variation of substitution rates}

Substitution rates were calculated from the LCA of cattle and dog assuming branch times of 83, 83 and 101 million years for cattle, dog and human lineages, respectively $[27,28]$. A dramatic variation of substitution rates was observed between and within chromosomes according to the human placement. Table S4 (see Additional file 1) summarizes the substitution rates of AR for each individual clone or locus on each chromosome. Chromosome X accumulated fewer substitutions than autosomal chromosomes (cattle $1.771 \pm 0.045, \operatorname{dog} 1.680 \pm 0.043$, and human $2.083 \pm 0.049 \times 10^{-9}$ change/site/year), supporting the existence of a higher mutation rate in the male than in the female germline [34]. Among autosomal chromosomes, HSA10 (Human chromosome 10), showed higher substitution rates (cattle $2.372 \pm 0.057, \operatorname{dog} 2.417 \pm$ 0.058 , and human $2.583 \pm 0.059 \times 10^{-9}$ change/site/year) compared to rates in chromosome 11 (cattle $2.151 \pm$ $0.028, \operatorname{dog} 1.916 \pm 0.025$, and human $2.022 \pm 0.025 \times 10^{-}$ 9 change/site/year). Substitution rates for HSA10 and HSA16 were significantly higher, while those for HSA14, HSA12 and HSA7 were significantly lower when compared to the average substitution rates in repetitive regions (t-test, all $\mathrm{P}<0.0001$, see Additional file 1 Table S4).

Similarly, substitution rates varied significantly among individual clones or loci within one chromosome (see Additional file 1 Fig. S2, Table S4). For example, contig 01.01 (mapped to HSA7:30,585,342-30,707,957 and CFA14:46,029,765-46,135,257) showed high substitution rates (cattle $2.371 \pm 0.080, \operatorname{dog} 1.788 \pm 0.065$, and human $2.020 \pm 0.068 \times 10^{-9}$ change/site/year), while contig 33.39 (mapped to HSA7:114,308,522-114,473,710 and CFA14:56,758,901-56,922,307) demonstrated low substitution rates (cattle $1.998 \pm 0.081, \operatorname{dog} 2.092 \pm$ 0.083 , and human $2.264 \pm 0.086 \times 10^{-9}$ change/site/year), even though both belonged to the same chromosomes (HSA7 and CFA14).

Histograms of substitution rates in non-overlapping 3-kb sliding windows for overall (A) and repetitive (B) sequences (with and without $\mathrm{CpG}$ sites) are shown in Fig. 1. ANOVA tests were performed on variation in branch lengths of 3-kb nonoverlapping windows between and within autosomal chromosomes for each species. These included 6 types of sequences: Overall, Overall-CG, Unique noncoding, Unique noncoding-CG, Repetitive, and Repetitive-CG. The overall sequence comprised 83 autosomal alignments containing 1761 windows; the unique noncoding regions comprised 83 autosomal alignments containing 1290 windows; and the repetitive regions comprised 83 autosomal alignments containing 347 windows. All tests were statistically significant at $\mathrm{P}$ $<0.0001$.

The relationships of overall substitution rate, branch length, $\mathrm{K} 2$ divergence, indel rate per $10 \mathrm{~kb}$, SINE\% and LINE\% on GC\% were complex and were best fit by a quadratic function $[9,11,21,37]$ (Fig. 2). It is worth noting that branch lengths (i.e. substitution rates after normalized by the divergence times) were well correlated among species - almost as well as the GC\% distribution (see Additional file 1 Fig. S2), although branch lengths and substitution rates did not seem to correlate with GC\% (Fig. 2). A positive coefficient for $\mathrm{GC} \%$ but a negative coefficient for the square of GC\% was obtained in all quadratic fit functions. The $\mathrm{K} 2$ divergences tended to increase over the GC\% interval below $45 \%$, whereas the plots tended to decrease above a GC\% of $45 \%$. However, all substitution rate and branch length fitting curves were relatively flat. This is consistent with an earlier observation of the discrepancy of rate estimation by the simple parametric model vs. the complicated rate model and maximum likelihood method at the high GC\% isochores [38]. The quadratic fits for substitution rate on GC\% had $\mathrm{r}^{2}$ values of $5.6 \%, 13.0 \%$ and $4.2 \%$ for cattle, dog, and human, respectively. The quadratic fits for K2 divergence on GC\% had $\mathrm{r}^{2}$ values of $12.6 \%, 8.1 \%$ and $9.0 \%$ for cattledog, cattle-human and dog-human comparisons, respectively. Correspondingly, the quadratic fits for indel on GC\% had $\mathrm{r}^{2}$ values of $19.8 \%, 7.8 \%$ and $14.6 \%$, respectively. The dramatic differences between SINE and LINE distribution relative to GC\% agreed with the previous observations of their differential insertion bias and retention behaviors $[4,9,14]$.

Loci with lower overall divergences were inspected for the presence of underlying RefSeq genes. As expected, many protein coding genes were under functional constraints. These constraints such as those on the FOXP2, MET and SCAP2 genes within the great CFTR region may explain the low overall divergences observed within that part of HSA7 [2]. When loci with high overall divergences were examined, it is interesting to note that a few protein coding genes were also detected. These included CSMD2 [39] (contig 38.45, HSA1:33,820,824-33,883,038), FDFT1 [40,41] and CTSB (contig 03.03, HSA8:11698086$11762835)[40,42,43]$. These loci retained higher substitution rates even if only the AR regions were considered (see Additional file 1 TableS4). 
C rate: $y=-1.2669+0.1447 x-0.0015 x^{2} \quad r^{2}=5.6 \%$ D rate: $y=-2.5665+0.1869 x-0.0019 x^{2} \quad r^{2}=13.0 \%$ $\mathrm{H}$ rate: $\mathrm{y}=-0.1614+0.0954 \mathrm{x}-0.0010 \mathrm{x}^{2} \quad \mathrm{r}^{2}=4.2 \%$

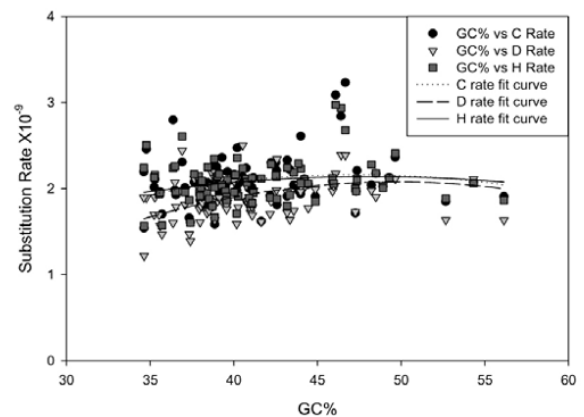

CD K2: $y=-0.4966+0.0362 x-0.0004 x^{2} \quad r^{2}=12.6 \%$ CH K2: $y=-0.3738+0.0329 x-0.0004 x^{2} \quad r^{2}=8.1 \%$ DH K2: $y=-0.3324+0.0302 x-0.0003 x^{2} \quad r^{2}=9.0 \%$

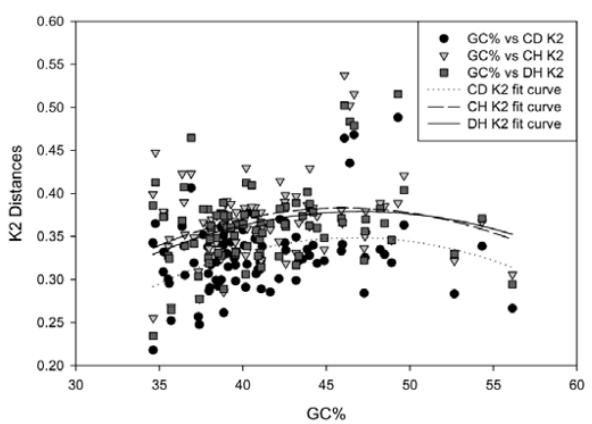

C SINE $\%: y=31.5776+0.3879 x-0.0144 x^{2} \quad r^{2}=24.9 \%$ D SINE $\%$ : $y=-40.6343+2.8569 x-0.0360 x^{2} \quad r^{2}=6.5 \%$ H SINE\%: $y=-1.4549+1.4641 \mathrm{x}-0.0236 \mathrm{x}^{2} \quad \mathrm{r}^{2}=12.5 \%$

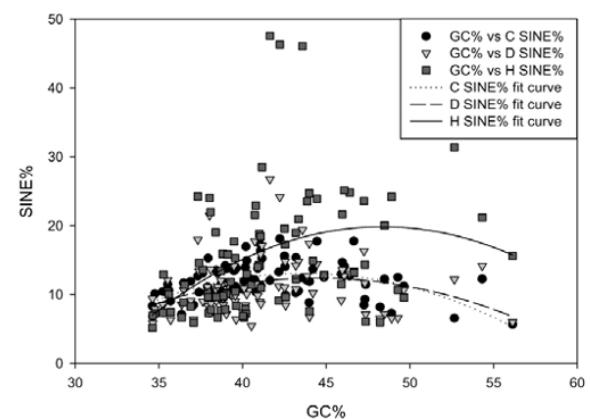

C length: $y=-0.1051+0.0120 x-0.0001 x^{2} \quad r^{2}=5.6 \%$ D length: $y=-0.2128+0.0155 x-0.0002 x^{2} \quad r^{2}=13.0 \%$ $\mathrm{H}$ length: $\mathrm{y}=-0.0159+0.0096 \mathrm{x}-0.0001 \mathrm{x}^{2} \quad r^{2}=4.2 \%$

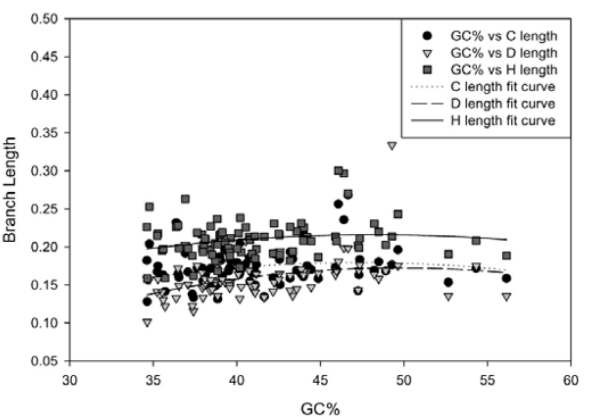

CD INDEL: $y=-82.6589+4.3803 x-0.0501 x^{2} \quad r^{2}=27.6 \%$ CH INDEL: $y=-67.9145+3.6155 x-0.0407 x^{2} \quad r^{2}=8.7 \%$ DH INDEL: $y=-138.8983+6.5654 \mathrm{x}-0.0679 \mathrm{x}^{2} \mathrm{r}^{2}=16.4 \%$

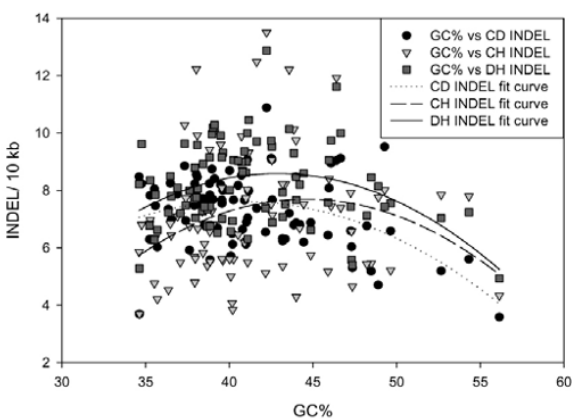

C LINE\%: $y=-17.1381+1.2164 x-0.0149 x^{2} \quad r^{2}=19.8 \%$ D LINE\%: $y=-31.4345+1.7548 x-0.0197 x^{2} \quad r^{2}=7.8 \%$ H LINE \%: $y=-26.2535+1.6255 x-0.0190 x^{2} \quad r^{2}=14.6 \%$

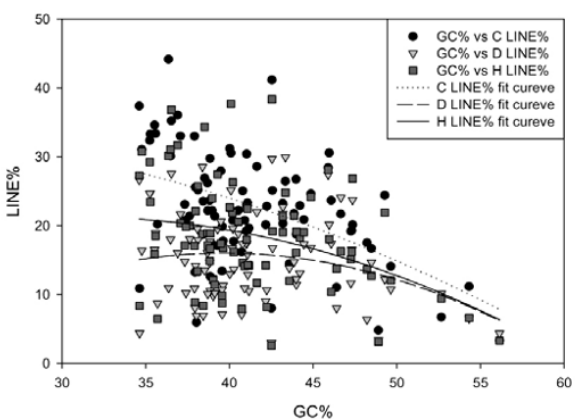

Figure 2

Scatter Plots and Quadratic Fits on Average GC\% for Substitution Rate, Branch Length, K2 Distances, INDEL/ 10 kb, SINE\% and LINE\%. Scatter plots of substitution rate, branch length, K2 distance, INDEL/IO kb, SINE\% and LINE\% against average GC\% in three-way alignments among cattle $(C)$, dog $(D)$, and human $(H)$. Substitution rates (the top left panel) and branch lengths (the top right panel) were estimated for each species by the PAML package (Methods). For each pairwise comparison in three-way alignments, $\mathrm{K} 2$ distances (the middle left panel) and large indel frequency ( $>100 \mathrm{bp}$ insertion/deletion event count per $10 \mathrm{~kb}$, the middle right panel) were calculated. Other sequence properties in each species such as SINE\% (the bottom left panel), LINE\% (the bottom right panel) were also plotted. Quadratic fit curves are derived on each plot and their formulas are provided on the top of each panel. 


\section{The differences of substitution rates between cattle and dog}

The overall substitution rates were estimated to be 2.026 $\pm 0.003,1.864 \pm 0.003$, and $2.016 \pm 0.003 \times 10^{-9}$ change $/$ site/year for cattle, dog and human, respectively (Table 1). Indeed, estimates of neutral mutation rates using ancient repeats (cattle $2.205 \pm 0.007, \operatorname{dog} 2.010 \pm 0.007$, and human $2.199 \pm 0.007 \times 10^{-9}$ change/site/year) were comparable to previous studies $\left(2.1-3.7 \times 10^{-9}\right.$ change/site/ year) [11], agreeing almost perfectly with the estimates from the human-mouse comparisons (i.e. $2.2 \times 10^{-9}$ and $4.5 \times 10^{-9}$ change/site/year in the human and mouse lineages) [9]. In all cases in Fig. 1 (Overall, Overall-CG, repetitive and repetitive-CG), the distributions of dog substitution rates (green) were shifted slightly to the left of those of cattle rates (blue), consistent with the faster rate of substitution in the cattle branch compared with the dog branch.

Relative rate tests were performed on a single merged alignment and on each of the 84 multiple alignments using Tajima's method $[44,45]$. Differences in mutation counts were assessed using the $\chi^{2}$ test based on the assumption that mutation would not show a species preference. When using human as an outgroup, cattle had faster rates of substitution as compared to dog. Although the difference was relatively small (6\%), it was significant by the $\chi^{2}$ test $(P<0.0001)$ when the merged alignment was tested. Almost two-thirds (54 out of 84 ) of the individual alignment rate tests supported that cattle had faster rates, while 11 of these rate tests supported that dog had faster rates (including 5 from the greater CFTR region). The remaining 19 out of 84 tests supported the molecular clock hypothesis for the cattle and dog lineages (including 3 from the greater CFTR region).

\section{Discussion}

One of the fundamental challenges in large-scale comparative genomic analysis is to build biologically meaningful multiple sequence alignments $[18,46]$. A variety of biological events are known to create insertion/deletions including lineage-specific amplification of tandem repeats, homology-mediated genomic deletions and transposition events [34]. Local alignment algorithms, combined with the removal and reinsertion strategy of repeat elements, have been shown to reduce the number of gaps in DNA alignments and increase sensitivity $[22,47]$. This is particularly important for aligning the species like rodents which have high genome-wide substitution rates. However, the aligned ancient repeats may be enriched for those in more slowly changing regions, while the fast changing repeats may be too divergent for detection and alignment [21]. On the other hand, global alignment algorithms seem appropriate for species with low substitution rates like cattle, dog and human. Comparative gene mapping and chromosome painting studies have indicated that a remarkably slow rate of chromosomal change exists within several mammalian orders. Artiodactyls and carnivores are more conserved relative to humans than rodents [48-53]. In terms of genomic divergence, previous data [2] also suggests that cattle and dog are more conserved relative to human. But global alignment algorithms assume colinearity between sequences and do not specifically handle synteny breaking events like transpositions, rearrangements (such as microinversions) or duplications [54]. For example, global alignment algorithms may be ineffective to treat lineage-specific repeats which are closely matched such as young SINEs and LINEs, creating suboptimal alignments [21]. These suboptimal alignments may lead to less accurate estimates of sequence divergence. Therefore, in this study, alignment parameters were optimized and a post-alignment filter was applied to overcome the above limitation of the global alignment algorithm. The post-alignment filter effectively removed the suboptimal alignments from the mlagan output. Such suboptimal alignments appeared abnormal because they had extreme fluctuations in genomic divergences compared to their flanking sequences and were always associated with multiple gaps. Similar genomic divergence results obtained in the current study compared to earlier reports $[10,12,30]$, confirm that our sequence datasets were representative and our alignment strategies were successful.

Our orthologous sequence datasets, comprised of 10.5 $\mathrm{Mb}$ of cattle sequences, $9.3 \mathrm{Mb}$ of dog sequences and 11.1 $\mathrm{Mb}$ of human sequences, were placed on all human chromosomes except for chr 9, 15, 19 and Y (see Additional file 1 Table S3). As a control for sample bias and rate variation among these genomic regions, we mapped randomly selected cattle BAC end sequences onto the human genome assembly Build35 (73,728 BES from CHORI-240 [31]). A comparison of these BES alignments to our largescale genomic alignments showed comparable results (G.E. Liu et al, unpublished results). Therefore, it is reasonable to believe that these datasets are sufficiently representative and robust to draw sound conclusions regarding rates and properties of mammalian genomic mutation.

However, our estimates were consistently larger than those in an earlier study of the greater CFTR region [2] and revealed significant rate differences between the cattle and dog lineages. Reanalysis of the alignments in that study (116 kb cattle, $122 \mathrm{~kb}$ dog, and $332 \mathrm{~kb}$ human sequences, $68 \mathrm{~kb}$ aligned bases) indicated that the dog-human divergence $(0.3335 \pm 0.0046$ change/site $)$ was significantly higher than the cattle-human divergence (0.3237 \pm 0.0045 change/site) (Relative rate test, $\mathrm{p}<0.001)$. Comparable divergences were derived from our AR regions (369 
$\mathrm{kb}$ cattle, $369 \mathrm{~kb}$ dog, and $485 \mathrm{~kb}$ human sequences, 157 $\mathrm{kb}$ aligned bases) from the same region (dog-human: $0.3856 \pm 0.0035$ change/site and cattle-human: $0.3870 \pm$ 0.0035 change/site). In our study, no significant rate difference was detected between cattle and dog (Relative rate test, $p=0.251$ ). One possible explanation is that the global alignment algorithm mlagan was used to create multiple alignments in the current study while pair-wise alignments were constructed by the local alignment algorithm - blastz in the earlier study. As discussed above, local alignment algorithms are known to be less efficient in identifying fast changing ancient repeats, which may be too divergent to detect and align. This could lead to the underestimation of the genomic divergences. On the other hand, use of a global alignment algorithm can recover the fast changing orthologous ancient repeats by taking into consideration the conservation of nearby unique flanking sequences. Discrepancies in the significance of rate variation between the small and large datasets also further highlight the importance of a large-scale sampling strategy.

As expected, different sequence classes were under different purifying selection pressures. Coding regions were under the strongest functional constraints with substitution rates at only half that of the overall substitution rates. It is interesting to note that substitution rates in unique noncoding portions were slightly less than overall substitution rates suggesting they may be under weak negative selection due to unidentified functional regions, regulatory domains, or unknown genes. Significantly higher substitution rates in repetitive elements before or after removing $\mathrm{CpG}$ dinucleotides indicate that $\mathrm{CpG}$ content is only partially the reason for high substitution rates. In addition, other factors like increased rates of gene conversion, relaxed purifying selection and unequal crossover among repeats may contribute to our observations.

The quadratic relationships between substitution rate, branch length, $\mathrm{K} 2$ divergence, indel rate per $10 \mathrm{~kb}$ and GC\% were derived to explain regional variation. These results suggest that fluctuations in GC\% predict an appreciable amount of the regional variation that was observed in mutation and indel rates, but leave the majority of the variation unexplained. Additional causes beyond GC\%, including CpG content, recombination and other as of yet unknown factors are needed to explain the variation among mutation rates. Significant variation in mutation rates across genomic regions and among sequence classes strongly demonstrates that future studies of genomic variation should include multiple regions from different chromosomes. Another important observation is that regional variation in mutation rate is correlated among cattle, dog and human lineages over time. Regional correlations of mutation rates have been demonstrated and quantified genome-wide in human-chimpanzee, humanmouse and human-rat comparisons $[9,14,20]$.

It is also interesting to note that a handful of protein coding genes were detected within a few cattle BAC clones with high neutral mutation rates. Several possible nonexclusive explanations for this phenomenon exist. For instance, the sequences compared may not have been orthologous. Within one gene family, paralogous genes could be confused with orthologous genes. Gene conversion may have occurred, which could considerably increase the genomic divergence [55]. In addition, high mutation rates or relaxed purifying selection could have occurred due to gene duplication [56,57]. These possibilities warrant further investigation. However, these rare events would not likely significantly change our estimates of mutation rates.

Measurement of the neutral mutation rate is crucial for validating molecular clock and neutral evolution theories $[58,59]$. The neutral mutation rate has been approximately estimated from neutral or close to neutral nonfunctional sites such as introns, pseudo-genes, unique noncoding intergenic regions, four-fold degenerate sites (4D sites) in coding regions (i.e. third codon position) and shared ancestral repeats. One way to identify regions under positive selection is to focus on DNA segments with significantly higher mutation rates [56]. Genomic regions that are changing significantly slower than the neutral rate because of purifying selection contain potentially conserved noncoding functional elements $[11,21]$.

Estimates of the neutral mutation rates in this study, which are in agreement with many previous reports $[2,12,30]$, show that mutation rates in the cattle and dog lineages are slower as compared with those in rodents. However, our estimates around 2.0-2.2 × 10-9 change/ site/year are in the lower end of the reported range (2.1$3.7 \times 10^{-9}$ change/site/year) [11]. These differences could result from the usage of $4 \mathrm{D}$ sites in the earlier studies, as nucleotides in coding regions may not be an ideal dataset because of codon usage bias and potential weak selection [34]. Regions that harbored large, low copy repeat sequences were excluded in this study to unambiguously determine the orthologous relationship. Such segmental duplicated regions may significantly inflate estimates of divergence due to non-orthologous sequence relationships $[46,60]$ or gene conversion [55].

The dataset presented here, though much large than those used previously $[2,12]$, is still a small part $(0.4 \%)$ of the cattle, dog and human genomes. It is also worth noting that a number of the common assumptions made about neutral mutation, genetic drift, generation-time and population size, can affect these estimates [34,61], and rate 
calculations could be confounded by incorrect estimates of species divergence times. More comprehensive genome sequences and polymorphism data will be required to further clarify the important role of mutation rates in mammalian evolution. Further study of the molecular mechanisms behind mutation will be essential to understand the causes of mutation rate variation. Additional analyses will become feasible as the bovine genome approaches the finishing stage.

\section{Additional note}

After the completion of this study, a comprehensive comparative analysis of the domestic dog genome reported similar genomic divergence estimates between dog and human [10].

\section{Conclusion}

The unique features of this study include 1) optimal multiple (not pairwise) alignments were carefully constructed using a global (not local) alignment algorithm; 2) the scale was considerably larger as compared to earlier reports using small datasets of protein coding sequences or targeted genomic regions and 3) Our results were statistically significant and unbiased as supported by the mapping results of genome-wide randomly selected cattle BAC end sequences.

Therefore, this analysis provides a large-scale and unbiased assessment of genome divergences and regional variations of substitution rates among cattle, dog and human. Cattle had faster average rates of substitution as compared to dog and the difference was $6 \%$. The global molecular clock needs to be adjusted to fit rates among mammalian species. These data will serve as a valuable baseline for future molecular evolution studies, especially in cattle and other livestock like sheep and pig.

\section{Methods}

The comparative analyses performed in the current study were similar to those previously published [46]. However, several improvements to the previous analyses were 1) the use of three-way multiple sequence alignments instead of comparison of several pairwise alignments; 2) the application of REV rate matrices and ML methods using the PAML package [62] in addition to the simple K2 calculation; and 3) the optimization of alignment parameters and filter thresholds to deal with larger sequence divergences.

\section{Orthologous sequences}

Large finished genomic sequences were retrieved from cattle BAC libraries (CH240 and RP42) from GenBank. Cattle sequence segments longer than $50 \mathrm{~kb}$ in length were then extracted and masked for common repeat elements $[63,64]$. Orthologous dog and human sequences were identified by sequence similarity searches [65] of cattle sequence queried against a formatted version of the assembled dog (canFam1, July 2004) and human (hg17, May 2004) genomes [32] using the following options (blastall -p blastn -U T -e 1e-05 -q -2 -r 1 -W 11 -G 3 -E 1 b 25). Overlapping sequences within a species were excluded based on the genome assembly coordinates and sequence identity. We excluded any accession located within a known duplicated region of the human genome [60], because duplicated regions of the genome complicate identification of orthologous segments and confound genomic divergence estimates $[18,46]$. Because the assembly of the dog genome is based on only seven-fold "shotgun" sequence coverage, our analysis was limited to genomic sequences completely finished and containing no gaps or internal ambiguous bases. A total of 84 cattle clones and subclones (see Additional file 1 Table S3) met these criteria: 69 were generated by Baylor College of Medicine Human Genome Sequencing Center [66]; 12 were generated in National Institutes of Health Intramural Sequencing Center [67] as a part of a targeted comparative sequencing effort (the ENCODE - ENCyclopedia Of DNA Elements Project) $[2,16,17]$; and the remaining 3 were generated at the University of Oklahoma, Advanced Center for Genome Technology [68]. A complete list of all accessions, their consensus assemblies, their map locations with respect to the genomes of dog and human and their sequence attributes are provided (see Additional file 1 Table S3).

\section{Genomic sequence alignment}

Orthologous sequences were extracted using parasight visualization software (J.A. Bailey, unpublished results) [69]. The mlagan algorithm [23] was used to construct all threeway multiple sequence global alignments. A subset of gap opening and gap extension penalties was chosen to minimize the frequency of both single-nucleotide substitution and insertion/deletion events in order to provide the most biologically meaningful optimal global alignment (See Results and Discussion). For equally parsimonious gap parameters, selected parameters (gap opening penalty of 1,000 and gap extension penalty of -10) were used so that known "young" transposition events were treated as a single insertion/deletion event. A total of 84 three-way multiple alignments for cattle, dog, and human (total alignment lengths $\sim 15.5 \mathrm{Mb}$ ) were constructed with mlagan using $~ 10 \mathrm{Mb}$ of genomic sequence from each species. All alignments were manually inspected for extreme fluctuations in genomic divergence. A suboptimal alignment was defined as any alignment which exceeded 3 standard deviations of the mean pairwise genomic divergence (window size $2 \mathrm{~kb}$, slide $100 \mathrm{bp}$ ). These regions were considered separately in the analysis (Table 1). A total of 89 such subalignments were classified as suboptimal for cattle (732 kb), dog (619 kb), and human (822 kb). Only a 
small fraction $(<5 \%)$ of all aligned bases was classified as suboptimal.

\section{Genomic divergence estimates}

The branch lengths were calculated by maximum likelihood using version 3.15 of the PAML package, which allows base frequency change, all bases exchangeability and rate heterogeneity across sites (Table 1) [62]. The most general reversible substitution model (REV) was used (model $=7$ ), rate variation among sites was allowed (fix_alpha $=0$ and ncatG $=5$ ), no molecular clock was assumed (clock $=0$ ), unrooted trees were used, and ambiguity characters were discarded (cleandata $=1$ ). Kimura's two-parameter (K2) method, which corrects for multiple events and transversion/transition mutational biases [70], was used to estimate genomic divergences in pairwise comparisons. Genomic divergences or branch lengths were always reported as the means \pm their standard deviations. Insertion/deletion events were not factored into these calculations [71]. Coding, UTR, unique noncoding and repetitive regions from the sequence alignments were extracted using MaM (Multiple Alignment Manipulator) $[36,72]$. Repeat coordinates were identified using the slow option of RepeatMasker v3.0.5 with an updated RepBase library for cattle. Five major classes of repeats were considered in this analysis (LINEs, SINEs, LTR, DNA Transposons, and others). In order to eliminate the possibility that more divergent or novel common repeats may not have been effectively masked by RepeatMasker, intraspecific sequence-similarity searches were performed. Exon definition was limited to well-annoted human genes (NCBI RefSeq) [35,73]. Among these, a total of 1,909 exons corresponding to 193 genes were analyzed. The coding regions were extracted from exonic sequences between CDS start and end sites. The UTR regions contained both 5'-UTR (between transcription start and CDS start sites) and 3'- UTR (between transcription end and CDS end sites). Unique noncoding regions excluded both exonic and repetitive regions. Non-overlapping sliding window analyses (3-kp in Fig. 1, Additional file 1 FigS5A and 500-bp in Fig. S5B) were performed using align_slider (J.A. Bailey, unpublished results). Substitution rates were calculated from the LCA of cattle and dog using branch length/time assuming branch times of the cattle, dog and human lineages of 83,83 and 101 mya, respectively $[27,28]$. All alignment attributes were maintained within a MySQL database which facilitated cross-referencing with various properties of the genomic sequence. Tajima's relative rate tests were performed on multiple alignments using MEGA3 [45]. ANOVA was performed to test variation in branch lengths of whole alignments or 3-kb nonoverlapping windows between and within autosomal chromosomes in cattle, dog, and human. Quadratic regression fits were implemented using the SigmaPlot software package.

\section{Abbreviations}

AR: ancestral repeat

LCA: last common ancestor

mya: million years ago

\section{Chr: Chromosome}

BES: BAC end sequences

BTA: Bos taurus autosome

CFA: Canis familiaris autosome

HSA: Homo sapiens autosome

\section{Authors' contributions}

GEL conceived and designed the experiments. GEL, CPVT, and LLS performed the experiments. GEL, CPVT, and TSS analyzed the data. GEL and LKM wrote the manuscript. All authors read and approved the final manuscript.

\section{Additional material}

\author{
Additional file 1 \\ Adobe pdf format, this Supplemental Material file includes Figure S1. \\ Optimization of Alignment Parameters. Figure S2. Cattle, Dog and \\ Human Sequence and Alignment Properties. Table S3. Map Locations of \\ Orthologous Trios in the Dog and Human Genome Assemblies. Table S4. \\ Substitution Rates of Ancestral Repeats in Cattle, Dog and Human. Fig- \\ ure S5. Substitution Rate Variation. \\ Click here for file \\ [http://www.biomedcentral.com/content/supplementary/1471- \\ 2164-7-140-S1.pdf]
}

\section{Acknowledgements}

We thank four anonymous reviewers for helpful comments on the manuscript. We thank M.D. Adams, E.E. Connor, and L.C. Gasbarre for critical reading of the manuscript, R.A. Gibbs, S.M. Kappes, and G.M. Weinstock for helpful comments in the preparation of this manuscript. We thank $M$. Brudno for insights to the lagan and mlagan aligning score matrixes. This work was supported in part by USDA CRIS Project No. 1265-31000-09000D and 1265-31000-08I-00D. Mention of trade names or commercial products in this article is solely for the purpose of providing specific information and does not imply recommendation or endorsement by the U.S. Department of Agriculture.

\section{References}

I. Margulies EH, Vinson JP, Miller W, Jaffe DB, Lindblad-Toh K, Chang JL, Green ED, Lander ES, Mullikin JC, Clamp M: An initial strategy for the systematic identification of functional elements in the human genome by low-redundancy comparative sequencing. Proc Natl Acad Sci USA 2005, I02:4795-4800.

2. Thomas JW, Touchman JW, Blakesley RW, Bouffard GG, BeckstromSternberg SM, Margulies EH, Blanchette M, Siepel AC, Thomas PJ, McDowell JC, Maskeri B, Hansen NF, Schwartz MS, Weber RJ, Kent WJ, Karolchik D, Bruen TC, Bevan R, Cutler DJ, Schwartz S, Elnitski 
L, Idol JR, Prasad AB, Lee-Lin SQ, Maduro VV, Summers TJ, Portnoy ME, Dietrich NL, Akhter N, Ayele K, Benjamin B, Cariaga K, Brinkley CP, Brooks SY, Granite S, Guan X, Gupta J, Haghighi P, Ho SL, Huang MC, Karlins E, Laric PL, Legaspi R, Lim MJ, Maduro QL, Masiello CA, Mastrian SD, McCloskey JC, Pearson R, Stantripop S, Tiongson EE, Tran JT, Tsurgeon C, Vogt JL, Walker MA, Wetherby KD, Wiggins LS, Young AC, Zhang LH, Osoegawa K, Zhu B, Zhao B, Shu CL, de Jong PJ, Lawrence CE, Smit AF, Chakravarti A, Haussler D, Green P, Miller W, Green ED: Comparative analyses of multi-species sequences from targeted genomic regions. Nature 2003, 424:788-93.

3. Kumar S: Molecular clocks: four decades of evolution. Nat Rev Genet 2005, 6:654-662.

4. Lander ES, Linton LM, Birren B, Nusbaum C, Zody MC, Baldwin J, Devon K, Dewar K, Doyle M, FitzHugh W, Funke R, Gage D, Harris K, Heaford A, Howland J, Kann L, Lehoczky J, LeVine R, McEwan P, McKernan K, Meldrim J, Mesirov JP, Miranda C, Morris W, Naylor J, Raymond C, Rosetti M, Santos R, Sheridan A, Sougnez C, StangeThomann N, Stojanovic N, Subramanian A, Wyman D, Rogers J, Sulston J, Ainscough R, Beck S, Bentley D, Burton J, Clee C, Carter N, Coulson A, Deadman R, Deloukas P, Dunham A, Dunham I, Durbin R, French L, Grafham D, Gregory S, Hubbard T, Humphray S, Hunt A, Jones M, Lloyd C, McMurray A, Matthews L, Mercer S, Milne S, Mullikin JC, Mungall A, Plumb R, Ross M, Shownkeen R, Sims S, Waterston RH, Wilson RK, Hillier LW, McPherson JD, Marra MA, Mardis ER, Fulton LA, Chinwalla AT, Pepin KH, Gish WR, Chissoe SL, WendI MC, Delehaunty KD, Miner TL, Delehaunty A, Kramer JB, Cook LL, Fulton RS, Johnson DL, Minx PJ, Clifton SW, Hawkins T, Branscomb E, Predki P, Richardson P, Wenning S, Slezak T, Doggett $\mathrm{N}$, Cheng JF, Olsen A, Lucas S, Elkin C, Uberbacher E, Frazier M, Gibbs RA, Muzny DM, Scherer SE, Bouck JB, Sodergren EJ, Worley KC, Rives CM, Gorrell JH, Metzker ML, Naylor SL, Kucherlapati RS, Nelson DL, Weinstock GM, Sakaki Y, Fujiyama A, Hattori M, Yada T, Toyoda A, Itoh T, Kawagoe C, Watanabe H, Totoki Y, Taylor T, Weissenbach J, Heilig R, Saurin W, Artiguenave F, Brottier P, Bruls T, Pelletier E, Robert C, Wincker P, Smith DR, Doucette-Stamm L, Rubenfield M, Weinstock K, Lee HM, Dubois J, Rosenthal A, Platzer M, Nyakatura G, Taudien S, Rump A, Yang H, Yu J, Wang J, Huang G, Gu J, Hood L, Rowen L, Madan A, Qin S, Davis RW, Federspiel NA, Abola AP, Proctor MJ, Myers RM, Schmutz J, Dickson M, Grimwood J, Cox DR, Olson MV, Kaul R, Raymond C, Shimizu N, Kawasaki K, Minoshima S, Evans GA, Athanasiou M, Schultz R, Roe BA, Chen F, Pan H, Ramser J, Lehrach H, Reinhardt R, McCombie WR, de la BM, Dedhia N, Blocker H, Hornischer K, Nordsiek G, Agarwala R, Aravind L, Bailey JA, Bateman A, Batzoglou S, Birney E, Bork P, Brown DG, Burge CB, Cerutti L, Chen HC, Church D, Clamp M, Copley RR, Doerks T, Eddy SR, Eichler EE, Furey TS, Galagan J, Gilbert JG, Harmon C, Hayashizaki Y, Haussler D, Hermjakob H, Hokamp K, Jang W, Johnson LS, Jones TA, Kasif S, Kaspryzk A, Kennedy S, Kent WJ, Kitts P, Koonin EV, Korf I, Kulp D, Lancet D, Lowe TM, McLysaght A, Mikkelsen T, Moran JV, Mulder N, Pollara VJ, Ponting CP, Schuler G, Schultz J, Slater G, Smit AF, Stupka E, Szustakowski J, Thierry-Mieg D, Thierry-Mieg J, Wagner L, Wallis J, Wheeler R, Williams A, Wolf YI, Wolfe KH, Yang SP, Yeh RF, Collins F, Guyer MS, Peterson J, Felsenfeld A, Wetterstrand KA, Patrinos A, Morgan MJ, De Jong P, Catanese JJ, Osoegawa K, Shizuya H, Choi S, Chen YJ, International Human Genome Sequencing Consortium: Initial sequencing and analysis of the human genome. Nature 2001, 409:860-92I.

5. IHGSC: Finishing the euchromatic sequence of the human genome. Nature 2004, 431:931-945.

6. Deininger PL, Batzer MA: Mammalian retroelements. Genome Res 2002, I 2: |455-| 465.

7. Deininger PL, Moran JV, Batzer MA, Kazazian HH Jr: Mobile elements and mammalian genome evolution. Curr Opin Genet Dev 2003, I3:65I-8.

8. Lunter G, Ponting CP, Hein J: Genome-Wide Identification of Human Functional DNA Using a Neutral Indel Model. PLoS Comput Biol 2006, 2:e5.

9. Waterston RH, Lindblad-Toh K, Birney E, Rogers J, Abril JF, Agarwal P, Agarwala R, Ainscough R, Alexandersson M, An P, Antonarakis SE, Attwood J, Baertsch R, Bailey J, Barlow K, Beck S, Berry E, Birren B, Bloom T, Bork P, Botcherby M, Bray N, Brent MR, Brown DG, Brown SD, Bult C, Burton J, Butler J, Campbell RD, Carninci P, Cawley S, Chiaromonte F, Chinwalla AT, Church DM, Clamp M, Clee C, Collins FS, Cook LL, Copley RR, Coulson A, Couronne O, Cuff J, Curwen V, Cutts T, Daly M, David R, Davies J, Delehaunty KD, Deri J, Dermitza- kis ET, Dewey C, Dickens NJ, Diekhans M, Dodge S, Dubchak I, Dunn DM, Eddy SR, Elnitski L, Emes RD, Eswara P, Eyras E, Felsenfeld A, Fewell GA, Flicek P, Foley K, Frankel WN, Fulton LA, Fulton RS, Furey TS, Gage D, Gibbs RA, Glusman G, Gnerre S, Goldman N, Goodstadt L, Grafham D, Graves TA, Green ED, Gregory S, Guigo R, Guyer M, Hardison RC, Haussler D, Hayashizaki Y, Hillier LW, Hinrichs A, Hlavina W, Holzer T, Hsu F, Hua A, Hubbard T, Hunt A, Jackson I, Jaffe DB, Johnson LS, Jones M, Jones TA, Joy A, Kamal M, Karlsson EK, Karolchik D, Kasprzyk A, Kawai J, Keibler E, Kells C, Kent WJ, Kirby A, Kolbe DL, Korf I, Kucherlapati RS, Kulbokas EJ, Kulp D, Landers T, Leger JP, Leonard S, Letunic I, LeVine R, Li J, Li M, Lloyd C, Lucas S, Ma B, Maglott DR, Mardis ER, Matthews L, Mauceli E, Mayer JH, McCarthy M, McCombie WR, McLaren S, McLay K, McPherson JD, Meldrim J, Meredith B, Mesirov JP, Miller W, Miner TL, Mongin E, Montgomery KT, Morgan M, Mott R, Mullikin JC, Muzny DM, Nash WE, Nelson JO, Nhan MN, Nicol R, Ning Z, Nusbaum C, O'Connor MJ, Okazaki Y, Oliver K, Overton-Larty E, Pachter L, Parra G, Pepin KH, Peterson J, Pevzner P, Plumb R, Pohl CS, Poliakov A, Ponce TC, Ponting CP, Potter S, Quail M, Reymond A, Roe BA, Roskin KM, Rubin EM, Rust AG, Santos R, Sapojnikov V, Schultz B, Schultz J, Schwartz MS, Schwartz S, Scott C, Seaman S, Searle S, Sharpe T, Sheridan A, Shownkeen R, Sims S, Singer JB, Slater G, Smit A, Smith DR, Spencer B, Stabenau A, Stange-Thomann N, Sugnet C, Suyama M, Tesler G, Thompson J, Torrents D, Trevaskis E, Tromp J, Ucla C, Ureta-Vidal A, Vinson JP, Von Niederhausern AC, Wade CM, Wall M, Weber RJ, Weiss RB, Wendl MC, West AP, Wetterstrand K, Wheeler R, Whelan S, Wierzbowski J, Willey D, Williams S, Wilson RK, Winter E, Worley KC, Wyman D, Yang S, Yang SP, Zdobnov EM, Zody MC, Lander ES: Initial sequencing and comparative analysis of the mouse genome. Nature 2002, 420:520-562.

10. Lindblad-Toh K, Wade CM, Mikkelsen TS, Karlsson EK, Jaffe DB, Kamal M, Clamp M, Chang JL, Kulbokas EJ III, Zody MC, Mauceli E, Xie X, Breen M, Wayne RK, Ostrander EA, Ponting CP, Galibert F, Smith DR, Dejong PJ, Kirkness E, Alvarez P, Biagi T, Brockman W, Butler J, Chin CW, Cook A, Cuff J, Daly MJ, DeCaprio D, Gnerre S, Grabherr M, Kellis M, Kleber M, Bardeleben C, Goodstadt L, Heger A, Hitte C, Kim L, Koepfli KP, Parker HG, Pollinger JP, Searle SM, Sutter NB, Thomas R, Webber C, Baldwin J, Abebe A, Abouelleil A, Aftuck L, Ait-Zahra M, Aldredge T, Allen N, An P, Anderson S, Antoine C, Arachchi H, Aslam A, Ayotte L, Bachantsang P, Barry A, Bayul T, Benamara M, Berlin A, Bessette D, Blitshteyn B, Bloom T, Blye J, Boguslavskiy L, Bonnet C, Boukhgalter B, Brown A, Cahill P, Calixte N, Camarata J, Cheshatsang Y, Chu J, Citroen M, Collymore A, Cooke P, Dawoe T, Daza R, Decktor K, DeGray S, Dhargay N, Dooley K, Dooley K, Dorje P, Dorjee K, Dorris L, Duffey N, Dupes A, Egbiremolen O, Elong R, Falk J, Farina A, Faro S, Ferguson D, Ferreira $P$, Fisher S, FitzGerald M, Foley K, Foley C, Franke A, Friedrich D, Gage D, Garber M, Gearin G, Giannoukos G, Goode T, Goyette A, Graham J, Grandbois E, Gyaltsen K, Hafez N, Hagopian D, Hagos B, Hall J, Healy C, Hegarty R, Honan T, Horn A, Houde N, Hughes L, Hunnicutt L, Husby M, Jester B, Jones C, Kamat A, Kanga B, Kells C, Khazanovich D, Kieu AC, Kisner P, Kumar M, Lance K, Landers T, Lara M, Lee W, Leger JP, Lennon N, Leuper L, LeVine S, Liu J, Liu X, Lokyitsang Y, Lokyitsang T, Lui A, Macdonald J, Major J, Marabella R, Maru K, Matthews C, McDonough S, Mehta T, Meldrim J, Melnikov A, Meneus L, Mihalev A, Mihova T, Miller K, Mittelman R, Mlenga V, Mulrain L, Munson G, Navidi A, Naylor J, Nguyen T, Nguyen N, Nguyen C, Nguyen T, Nicol R, Norbu N, Norbu C, Novod N, Nyima T, Olandt P, O'Neill B, O'Neill K, Osman S, Oyono L, Patti C, Perrin D, Phunkhang P, Pierre F, Priest M, Rachupka A, Raghuraman S, Rameau R, Ray V, Raymond C, Rege F, Rise C, Rogers J, Rogov P, Sahalie J, Settipalli S, Sharpe T, Shea T, Sheehan M, Sherpa N, Shi J, Shih D, Sloan J, Smith C, Sparrow T, Stalker J, Stange-Thomann N, Stavropoulos S, Stone C, Stone S, Sykes S, Tchuinga P, Tenzing P, Tesfaye S, Thoulutsang D, Thoulutsang Y, Topham K, Topping I, Tsamla T, Vassiliev H, Venkataraman V, Vo A, Wangchuk T, Wangdi T, Weiand M, Wilkinson J, Wilson A, Yadav S, Yang S, Yang X, Young G, Yu Q, Zainoun J, Zembek L, Zimmer A, Lander ES: Genome sequence, comparative analysis and haplotype structure of the domestic dog. Nature 2005, 438:803-819.

II. Hardison RC, Roskin KM, Yang S, Diekhans M, Kent WJ, Weber R, Elnitski L, Li J, O'Connor M, Kolbe D, Schwartz S, Furey TS, Whelan S, Goldman N, Smit A, Miller W, Chiaromonte F, Haussler D: Covariation in frequencies of substitution, deletion, transposition, and recombination during eutherian evolution. Genome Res 2003, 13:13-26. 
12. Kumar S, Subramanian S: Mutation rates in mammalian genomes. Proc Natl Acad Sci USA 2002, 99:803-808.

13. Venter JC, Adams MD, Myers EW, Li PW, Mural RJ, Sutton GG, Smith HO, Yandell M, Evans CA, Holt RA, Gocayne JD, Amanatides P, Ballew RM, Huson DH, Wortman JR, Zhang Q, Kodira CD, Zheng XH, Chen L, Skupski M, Subramanian G, Thomas PD, Zhang J, Gabor Miklos GL, Nelson C, Broder S, Clark AG, Nadeau J, McKusick VA, Zinder N, Levine AJ, Roberts RJ, Simon M, Slayman C, Hunkapiller M, Bolanos R, Delcher A, Dew I, Fasulo D, Flanigan M, Florea L, Halpern A, Hannenhalli S, Kravitz S, Levy S, Mobarry C, Reinert K, Remington K, Abu-Threideh J, Beasley E, Biddick K, Bonazzi V, Brandon R, Cargill M, Chandramouliswaran I, Charlab R, Chaturvedi K, Deng Z, Di Francesco V, Dunn P, Eilbeck K, Evangelista C, Gabrielian AE, Gan W, Ge W, Gong F, Gu Z, Guan P, Heiman TJ, Higgins ME, Ji RR, Ke Z, Ketchum KA, Lai Z, Lei Y, Li Z, Li J, Liang Y, Lin X, Lu F, Merkulov GV, Milshina N, Moore HM, Naik AK, Narayan VA, Neelam B, Nusskern D, Rusch DB, Salzberg S, Shao W, Shue B, Sun J, Wang Z, Wang A, Wang X, Wang J, Wei M, Wides R, Xiao C, Yan C, Yao A, Ye J, Zhan M, Zhang W, Zhang H, Zhao Q, Zheng L, Zhong F, Zhong W Zhu S, Zhao S, Gilbert D, Baumhueter S, Spier G, Carter C, Cravchik A, Woodage T, Ali F, An H, Awe A, Baldwin D, Baden H, Barnstead M, Barrow I, Beeson K, Busam D, Carver A, Center A, Cheng ML, Curry L, Danaher S, Davenport L, Desilets R, Dietz S, Dodson K, Doup L, Ferriera S, Garg N, Gluecksmann A, Hart B, Haynes J, Haynes C, Heiner C, Hladun S, Hostin D, Houck J, Howland T, lbegwam C Johnson J, Kalush F, Kline L, Koduru S, Love A, Mann F, May D, McCawley S, Mclntosh T, McMullen I, Moy M, Moy L, Murphy B, Nelson K, Pfannkoch C, Pratts E, Puri V, Qureshi H, Reardon M, Rodriguez R, Rogers $\mathrm{YH}$, Romblad D, Ruhfel B, Scott R, Sitter C, Smallwood M, Stewart E, Strong R, Suh E, Thomas R, Tint NN, Tse S, Vech C, Wang G, Wetter J, Williams S, Williams M, Windsor S, WinnDeen E, Wolfe K, Zaveri J, Zaveri K, Abril JF, Guigo R, Campbell M], Sjolander KV, Karlak B, Kejariwal A, Mi H, Lazareva B, Hatton T, Narechania A, Diemer K, Muruganujan A, Guo N, Sato S, Bafna V, Istrail S, Lippert R, Schwartz R, Walenz B, Yooseph S, Allen D, Basu A, Baxendale J, Blick L, Caminha M, Carnes-Stine J, Caulk P, Chians YH, Coyne M, Dahlke C, Mays A, Dombroski M, Donnelly M, Ely D, Esparham S, Fosler C, Gire H, Glanowski S, Glasser K, Glodek A Gorokhov M, Graham K, Gropman B, Harris M, Heil J, Henderson S, Hoover J, Jennings D, Jordan C, Jordan J, Kasha J, Kagan L, Kraft C, Levitsky A, Lewis M, Liu X, Lopez J, Ma D, Majoros W, McDaniel J, Murphy S, Newman M, Nguyen T, Nguyen N, Nodell M: The sequence of the human genome. Science 200I, 29 I: I304-5 I.

14. Gibbs RA, Weinstock GM, Metzker ML, Muzny DM, Sodergren EJ Scherer S, Scott G, Steffen D, Worley KC, Burch PE, Okwuonu G, Hines S, Lewis L, DeRamo C, Delgado O, Dugan-Rocha S, Miner G, Morgan M, Hawes A, Gill R, Celera, Holt RA, Adams MD, Amanatides PG, Baden-Tillson H, Barnstead M, Chin S, Evans CA, Ferriera S, Fosler C, Glodek A, Gu Z, Jennings D, Kraft CL, Nguyen T, Pfannkoch CM, Sitter C, Sutton GG, Venter JC, Woodage T, Smith D, Lee HM, Gustafson E, Cahill P, Kana A, Doucette-Stamm L, Weinstock K, Fechtel K, Weiss RB, Dunn DM, Green ED, Blakesley RW, Bouffard GG, de Jong PJ, Osoegawa K, Zhu B, Marra M, Schein J, Bosdet I, Fjell C, Jones S, Krzywinski M, Mathewson C, Siddiqui A, Wye N, McPherson J, Zhao S, Fraser CM, Shetty J, Shatsman S, Geer K, Chen Y, Abramzon S, Nierman WC, Havlak PH, Chen R, Durbin KJ, Egan A, Ren Y, Song XZ, Li B, Liu Y, Qin X, Cawley S, Worley KC, Cooney AJ, D'Souza LM, Martin K, Wu JQ, Gonzalez-Garay ML, Jackson AR, Kalafus KJ, McLeod MP, Milosavljevic A, Virk D, Volkov A, Wheeler DA, Zhang Z, Bailey JA, Eichler EE, Tuzun E, Birney E, Mongin E, Ureta-Vidal A, Woodwark C, Zdobnov E, Bork P, Suyama M, Torrents $D$, Alexandersson $M$, Trask BJ, Young JM, Huang $H$, Wang $H$, Xing $H$, Daniels S, Gietzen D, Schmidt J, Stevens K, Vitt U, Wingrove J. Camara F, Mar AM, Abril JF, Guigo R, Smit A, Dubchak I, Rubin EM, Couronne O, Poliakov A, Hubner N, Ganten D, Goesele C, Humme $\mathrm{O}$, Kreitler T, Lee YA, Monti J, Schulz H, Zimdahl H, Himmelbauer H, Lehrach $\mathrm{H}$, Jacob HJ, Bromberg S, Gullings-Handley J, Jensen-Seaman MI, Kwitek AE, Lazar J, Pasko D, Tonellato PJ, Twigger S, Ponting CP, Duarte JM, Rice S, Goodstadt L, Beatson SA, Emes RD, Winter EE, Webber C, Brandt P, Nyakatura G, Adetobi M, Chiaromonte F, Elnitski L, Eswara P, Hardison RC, Hou M, Kolbe D, Makova K, Miller W, Nekrutenko A, Riemer C, Schwartz S, Taylor J, Yang S, Zhang Y, Lindpaintner K, Andrews TD, Caccamo M, Clamp M, Clarke L, Curwen V, Durbin R, Eyras E, Searle SM, Cooper GM, Batzoglou S, Brudno M, Sidow A, Stone EA, Venter JC, Payseur BA, Bourque G, Lopez-Otin C, Puente XS, Chakrabarti K, Chatterji S, Dewey C, Pachter L, Bray
N, Yap VB, Caspi A, Tesler G, Pevzner PA, Haussler D, Roskin KM, Baertsch R, Clawson H, Furey TS, Hinrichs AS, Karolchik D, Kent WJ, Rosenbloom KR, Trumbower H, Weirauch M, Cooper DN, Stenson PD, Ma B, Brent M, Arumugam M, Shteynberg D, Copley RR, Taylor MS, Riethman H, Mudunuri U, Peterson J, Guyer M, Felsenfeld A, Old S, Mockrin S, Collins F: Genome sequence of the Brown Norway rat yields insights into mammalian evolution. Nature 2004, 428:493-52I.

15. The Chimpanzee Sequencing and Analysis Consortium: Initial sequence of the chimpanzee genome and comparison with the human genome. Nature 2005, 437:69-87.

16. The ENCODE Project Consortium: The ENCODE (ENCyclopedia Of DNA Elements) Project. Science 2004, 306:636-640.

17. The ENCODE Project: ENCyclopedia Of DNA Elements [http://www.genome.gov/ /0005/07]

18. Chen FC, Vallender EJ, Wang H, Tzeng CS, Li WH: Genomic divergence between human and chimpanzee estimated from large-scale alignments of genomic sequences. J Hered 200I, 92:48I-9.

19. Ebersberger I, Metzler D, Schwarz C, Paabo S: Genomewide comparison of DNA sequences between humans and chimpanzees. American Journal of Human Genetics 2002, 70:1490-7.

20. Smith NG, Webster MT. Ellegren $\mathrm{H}$ : Deterministic mutation rate variation in the human genome. Genome Res 2002, I 2:1350-6.

21. Yang S, Smit AF, Schwartz S, Chiaromonte F, Roskin KM, Haussler D, Miller W, Hardison RC: Patterns of insertions and their covariation with substitutions in the rat, mouse, and human genomes. Genome Res 2004, 14:5 17-527.

22. Schwartz S, Kent W], Smit A, Zhang Z, Baertsch R, Hardison RC Haussler D, Miller W: Human-mouse alignments with BLASTZ. Genome Res 2003, 13:103-107.

23. Brudno M, Do CB, Cooper GM, Kim MF, Davydov E, Green ED, Sidow A, Batzoglou S: LAGAN and Multi-LAGAN: efficient tools for large-scale multiple alignment of genomic DNA. Genome Res 2003, 13:721-731.

24. 2004 Advisory Dog Genome Assembled [http:// www.genome.gov/I25I|476]

25. Bos taurus (bovine) genome view [http://www.ncbi.nlm.nih.gov/ mapview/map search.cgi?taxid=9913]

26. Children's Hospital Oakland Research Institute: BAC and PAC resources [http://bacpac.chori.org/]

27. Hedges SB: The origin and evolution of model organisms. Nat Rev Genet 2002, 3:838-849.

28. Springer MS, Murphy WJ, Eizirik E, O'Brien SJ: Placental mammal diversification and the Cretaceous-Tertiary boundary. Proc Natl Acad Sci USA 2003, 100:1056-1061.

29. Wall DP, Fraser HB, Hirsh AE: Detecting putative orthologs. Bioinformatics 2003, 19:1710-171I.

30. Madsen O, Scally M, Douady CJ, Kao DJ, DeBry RW, Adkins R, Amrine HM, Stanhope MJ, de Jong WW, Springer MS: Parallel adaptive radiations in two major clades of placental mammals. Nature 200I, 409:610-614.

31. Taxonomy browser (Bos taurus) [http://www.ncbi.nlm.nih.gov/ Taxonomy/Browser/wwwtax.cgi?id=9913]

32. UCSC Genome Bioinformatics [http://genome.ucsc.edu/]

33. Cattle Genomic Divergence Project [http:// bfgl.anri.barc.usda.gov/divergence]

34. Li W: Molecular Evolution Sunderland, MA: Sinauer Associates; 1997.

35. Pruitt KD, Tatusova T, Maglott DR: NCBI Reference Sequence (RefSeq): a curated non-redundant sequence database of genomes, transcripts and proteins. Nucleic Acids Res 2005, 33:D50I-D504.

36. Alkan C, Tuzun E, Buard J, Lethiec F, Eichler EE, Bailey JA, Sahinalp SC: Manipulating multiple sequence alignments via $\mathrm{MaM}$ and WebMaM. Nucleic Acids Res 2005, 33:W295-W298.

37. Bernardi G: Misunderstandings about isochores. Part I. Gene 200I, 276:3-13.

38. Hurst LD, Williams E): Covariation of GC content and the silent site substitution rate in rodents: implications for methodology and for the evolution of isochores. Gene 2000, 26 I: 107-II4.

39. Lau WL, Scholnick SB: Identification of two new members of the CSMD gene family small star, filled. Genomics 2003, 82:4I2-4I5.

40. Plis-Finarov A, Hudson H, Roe B, Ron M, Seroussi E: Mapping of the GATA4, NEIL2, FDFTI genes and CTSB-associated micros- 
atellites to the centromeric region of BTA8. Anim Genet 2004, 35: $154-155$

4I. Schechter I, Conrad DG, Hart I, Berger RC, McKenzie TL, Bleskan J, Patterson $D$ : Localization of the squalene synthase gene (FDFTI) to human chromosome 8p22-p23.I. Genomics 1994, 20:116-118.

42. Fong D, Chan MM, Hsieh WT, Menninger JC, Ward DC: Confirmation of the human cathepsin $B$ gene (CTSB) assignment to chromosome 8. Hum Genet 1992, 89:10-12.

43. Russo V, Fontanesi L, Davoli R, Nanni CL, Cagnazzo M, Buttazzoni L, Virgili R, Yerle M: Investigation of candidate genes for meat quality in dry-cured ham production: the porcine cathepsin B (CTSB) and cystatin B (CSTB) genes. Anim Genet 2002, 33:|23-|3|.

44. Tajima F: Simple methods for testing the molecular evolutionary clock hypothesis. Genetics 1993, 135:599-607.

45. Kumar S, Tamura K, Nei M: MEGA3: Integrated software for Molecular Evolutionary Genetics Analysis and sequence alignment. Brief Bioinform 2004, 5:150-163.

46. Liu G, Zhao S, Bailey JA, Sahinalp SC, Alkan C, Tuzun E, Green ED, Eichler EE: Analysis of primate genomic variation reveals a repeat-driven expansion of the human genome. Genome Res 2003, 13:358-368

47. Blanchette M, Kent WJ, Riemer C, Elnitski L, Smit AF, Roskin KM, Baertsch R, Rosenbloom K, Clawson H, Green ED, Haussler D, Miller $\mathrm{W}$ : Aligning multiple genomic sequences with the threaded blockset aligner. Genome Res 2004, 14:708-7।5.

48. Ihara N, Takasuga A, Mizoshita K, Takeda H, Sugimoto M, Mizoguchi Y, Hirano T, Itoh T, Watanabe T, Reed KM, Snelling WM, Kappes SM, Beattie CW, Bennett GL, Sugimoto Y: A comprehensive genetic map of the cattle genome based on $\mathbf{3 8 0 2}$ microsatellites. Genome Res 2004, 14:1987-1998.

49. Everts-van der Wind A, Kata SR, Band MR, Rebeiz M, Larkin DM, Everts RE, Green CA, Liu L, Natarajan S, Goldammer T, Lee JH, McKay S, Womack JE, Lewin HA: A 1463 gene cattle-human comparative map with anchor points defined by human genome sequence coordinates. Genome Res 2004 i 4: 1424- 4337.

50. Larkin DM, Everts-van der Wind A, Rebeiz M, Schweitzer PA, Bachman S, Green C, Wright CL, Campos EJ, Benson LD, Edwards J, Liu L, Osoegawa K, Womack JE, de Jong PJ, Lewin HA: A cattle-human comparative map built with cattle BAC-ends and human genome sequence. Genome Res 2003, 13:1966-1972.

51. Murphy WJ, Larkin DM, Everts-van der Wind A, Bourque G, Tesler G, Auvil L, Beever JE, Chowdhary BP, Galibert F, Gatzke L, Hitte C Meyers SN, Milan D, Ostrander EA, Pape G, Parker HG, Raudsepp T, Rogatcheva MB, Schook LB, Skow LC, Welge M, Womack JE, O'Brien SJ, Pevzner PA, Lewin HA: Dynamics of mammalian chromosome evolution inferred from multispecies comparative maps. Science 2005, 309:613-617.

52. Murphy WJ, Pevzner PA, O'Brien SJ: Mammalian phylogenomics comes of age. Trends Genet 2004, 20:63I-639.

53. Everts-van der Wind A, Larkin DM, Green CA, Elliott JS, Olmstead CA, Chiu R, Schein JE, Marra MA, Womack JE, Lewin HA: A highresolution whole-genome cattle-human comparative map reveals details of mammalian chromosome evolution. Proc Natl Acad Sci USA 2005, 102: |8526-|853।.

54. Brudno M, Malde S, Poliakov A, Do CB, Couronne O, Dubchak I, Batzoglou S: Glocal alignment: finding rearrangements during alignment. Bioinformatics 2003, 19(SuppI I):i54-i62.

55. Hurles ME: Gene conversion homogenizes the CMTIA paralogous repeats. BMC Genomics 200 I, 2: I I.

56. Johnson ME, Viggiano L, Bailey JA, Abdul-Rauf M, Goodwin G, Rocchi $M$, Eichler EE: Positive selection of a gene family during the emergence of humans and African apes. Nature 200I, 413:5|4-9.

57. Lynn DJ, Freeman AR, Murray C, Bradley DG: A genomics approach to the detection of positive selection in cattle: adaptive evolution of the T-cell and natural killer cell-surface protein CD2. Genetics 2005, I70:। 189-II96.

58. Kimura M: Rare variant alleles in the light of the neutral theory. Molecular Biology \& Evolution 1983, I:84-93.

59. Zuckerkandl E, Pauling L: Molecules as documents of evolutionary history. Journal of Theoretical Biology 1965, 8:357-66.
60. Bailey JA, Gu Z, Clark RA, Reinert K, Samonte RV, Schwartz S, Adams MD, Myers EW, Li PW, Eichler EE: Recent segmental duplications in the human genome. Science 2002, 297: 1003-7.

61. Nei M, Tateno $Y$ : Interlocus variation of genetic distance and the neutral mutation theory. Proc Natl Acad Sci USA 1975, 72:2758-2760.

62. Yang Z: PAML: a program package for phylogenetic analysis by maximum likelihood. Comput Appl Biosci 1997, 13:555-556.

63. Smit AF: Interspersed repeats and other mementos of transposable elements in mammalian genomes. Current Opinion in Genetics \& Development 1999, 9:657-63.

64. RepeatMasker [http://www.repeatmasker.org/]

65. Altschul SF, Gish W, Miller W, Myers EW, Lipman DJ: Basic local alignment search tool. J Molec Biol 1990, 21 5:403-4IO.

66. Human Genome Sequencing Center at Baylor College of Medicine [http://www.hgsc.bcm.tmc.edu/projects/bovine/]

67. NIH Intramural Sequencing Center [http://www.nisc.nih.gov/]

68. University of Oklahoma's Advanced Center for Genome Technology [http://www.genome.ou.edu/]

69. Parasight [http://humanparalogy.gs.washington.edu/parasight/]

70. Kimura M: A simple method for estimating evolutionary rates of base substitutions through comparative studies of nucleotide sequences. I Mol Evol 1980, 16: III-20.

7I. Britten RJ, Rowen L, Williams J, Cameron RA: Majority of divergence between closely related DNA samples is due to indels. Proc Natl Acad Sci USA 2003, 100:466I-4665.

72. MaM: Multiple alignment Manipulator [http://comp bio.cs.sfu.ca/MAM.htm]

73. NCBI Reference Sequences (RefSeq) [http:// www.ncbi.nlm.nih.gov/RefSeq/]

Publish with Biomed Central and every scientist can read your work free of charge

"BioMed Central will be the most significant development for disseminating the results of biomedical research in our lifetime. "

Sir Paul Nurse, Cancer Research UK

Your research papers will be:

- available free of charge to the entire biomedical community

- peer reviewed and published immediately upon acceptance

- cited in PubMed and archived on PubMed Central

- yours - you keep the copyright

Submit your manuscript here:

http://www.biomedcentral.com/info/publishing_adv.asp

BiolMedcentral 